\title{
Online Grocery Shopping: a Boom, Hype, or Black Ice?
}

\author{
Stefan Bongard \\ Department of Services and Consulting, University of Applied Sciences Ludwigshafen am Rhein, \\ Ludwigshafen am Rhein, Germany \\ E-mail: stefan.bongard@hs-lu.de
}

Received 13 February 2017; accepted 24 March 2017

\begin{abstract}
Buying groceries online is no longer a novel phenomenon: recent studies (2016) show that in Germany, approximately 30 percent of potential buyers have already purchased groceries online. Together with the latest grocery shopping services from the online giant Amazon (e.g. Amazon Fresh and Amazon go), this growing sector of online food and drink retail comprises an attractive field for economic research. General research objectives in this field investigate sustainable business models, planning of logistics structures, and changes in buyer behaviour. The purpose of this present study was to analyze buyer behavior in the field of online food retail based on a process design derived from principles of Quality Management. A convenience sample of 822 valid data records was collected from NovemberDecember 2016 using a sophisticated online survey tool. The data set contains responses from 256 individuals who had already bought groceries online, while the rest of the respondents had not previously purchased groceries online. The study strongly underscores the great potential of online retail grocery industry, while also detailing the potential risks associated with this business model, such as low profit margins and packaging issues.
\end{abstract}

Keywords: applied research, beverages, individual retail mix, food, groceries, online grocery shopping, online retail.

JEL Classification: L66.

Conference topic: Informational Society: Challenges, Solutions and Tendencies.

\section{Introduction}

According to recent studies, $30 \%$ of people aged 14 years or older in Germany have purchased groceries online (Rohleder 2016). This figure suggests that the market for online grocery shopping has long ceased to be a novel phenomenon. The recent news about the acquisition of approximately 400 Tengelmann grocery stores by German grocery giants Edeka and Rewe, however, indicates that brick and mortar stores still do seem to be the preferred business model in the retail grocery industry (Der Tengelmann-Deal 2016). Against this backdrop, there are also reports that Amazon is becoming an increasingly active player in this branch - and not just online, but also with its delivery service Amazon Fresh and its first brick-and-mortar store (Amazon eröffnet 2016; Zdrzalek 2016).

This short outline of the current situation in the online retail grocery industry reveals it to be a field ripe for research, with many unresolved questions. In addition to general questions regarding the future growth of the online retail grocery industry and the profile of a typical online shopper, other topics to investigate include which business models could offer sustainable success, as well as what impact online grocery shopping has on the logistical structures of the supply chain.

Using an online survey, research-related data was collected from 957 individuals during December 2016. Validation of the data for fully completed responses reduced the number that could be included in the study to 822 . This survey is not representative and constitutes a "convenience sample" (Maurer, Jandura 2009). In comparison to the representative bitkom study (Rohleder 2016), for instance, the youngest age group (14-29 years old) is much more strongly represented in our study than in the bitkom study (55\% in our study vs. $26 \%$ in bitkom). In addition, it was not possible to reach participants from all federal states of Germany in this study. What does speak for the quality of our data pool, however, is that fact that key findings from the bitkom study were confirmed by our data (e.g. the percentage of online shoppers and their high rates of satisfaction).

(C) 2017 S. Bongard. Published by VGTU Press. This is an open-access article distributed under the terms of the Creative Commons Attribution (CC BY 4.0) License, which permits unrestricted use, distribution, and reproduction in any medium, provided the original author and source are credited. 


\section{Previous Studies}

According to a representative survey conducted by bitkom Research in 2016, 28\% of respondents indicate that they have already purchased groceries online at least once. In this study, shopper satisfaction is at a very high level, with 93\% being "very satisfied" or "rather satisfied" (Rohleder 2016).

The "Lebensmittel E-Commerce 2016" (Grocery Food E-Commerce 2016) study from the EHI Retail Institute (Berens 2016) looks at 35 online shops offering a full product range and delivery of fresh and refrigerated foods where customers can place an order for nearly a week's worth of groceries.

In a 2015 Gesellschaft für Konsumforschung (Society for Consumer Research) study titled "E-Commerce Wachstum oder Grenzen?" (E-Commerce: Growth or Limits?), it is predicted that by 2025, the online "Grocery and Household Items" segment will double from $8 \%$ to $16 \%$ as a share of all online commerce (Gassmann 2015; Lichtner 2015).

The DHL study "Einkaufen 4.0" (Shopping 4.0) (Deutsche Post DHL 2012) places a focus on identifying the different types of Internet shoppers. It also contains an essay on retail commerce by Christian Heitmeyer, the initiator and the founder of Allyouneedfresh (www.allyouneedfresh.com), which call itself the "first all-around-retail-platform in the grocery business" (Heitmeyer 2012).

A broad discussion about the general question of consumer choice between online or retails stores can be found in a paper of Burinskiene/Daskevic (Burinskiene, Daskevic 2014).

\section{Methodology}

For this study, an online questionnaire was designed that was accessible online via a link. The link was sent by email to various mailing lists (e.g. members of the University of Applied Sciences Ludwigshafen am Rhein) and posted on social media outlets. During the timeframe from 24 November - 29 December 2016, a total of 957 datasets were gathered. In order to sort out the datasets that did not contain enough valid answers, a validation filter was applied, reducing the number of usable datasets to 822 . The validation filter was designed to include all surveys for analysis in which at least five of the six demographic questions were answered (83\%), and at least seven of the other nine questions were answered (78\%).

This study does not attempt to examine every possible facet of the topic. Instead, the goal was to investigate selected issues from this topical area. The basis for choosing these topics included in-class discussions and working through case studies with students in the context of a course on Quality Management. Accordingly, the questions were developed following the methodology of quality management using the framework of a process model. For this study, six different phases of the online shopping process were identified, as depicted in Table 1.

Table 1. Phase Model of Online Grocery Shopping (Source: compiled by author)

\begin{tabular}{c|c|c}
\hline $\begin{array}{c}\text { Process } \\
\text { phase }\end{array}$ & Process & $\begin{array}{c}\text { Number of questions } \\
\text { assigned }\end{array}$ \\
\hline 1 & Log-in/Check-in & 2 \\
\hline 2 & Shopping/Product Assortment & 2 \\
\hline 3 & Receiving/Delivery/Pick-Up & 2 \\
\hline 4 & Payment/Check-out & 1 \\
\hline 5 & Unpacking: Packaging/Disposal & - \\
\hline 6 & Returns/Complaints & \\
\hline
\end{tabular}

As shown in this table, not all phases of the process were assigned questions. The reason for this was to keep the questionnaire as short as possible so as to attain a high degree of data quality: the longer an online survey is, the higher the risk that the user terminates the survey before completion, making the entire dataset unusable for analysis. Future versions of this questionnaire are planned to also survey other phases of the online grocery shopping process.

\section{Results}

At the beginning of the survey, an image with a small selection of foods and drinks is displayed. These foods and drinks could be used for a nice night out with friends, including sphaghetti Bolognese with salad, soft drinks and beer, ice cream and grapes for dessert, and crackers for a snack. The willingness of the participants to buy these articles was identified with a heat map. 


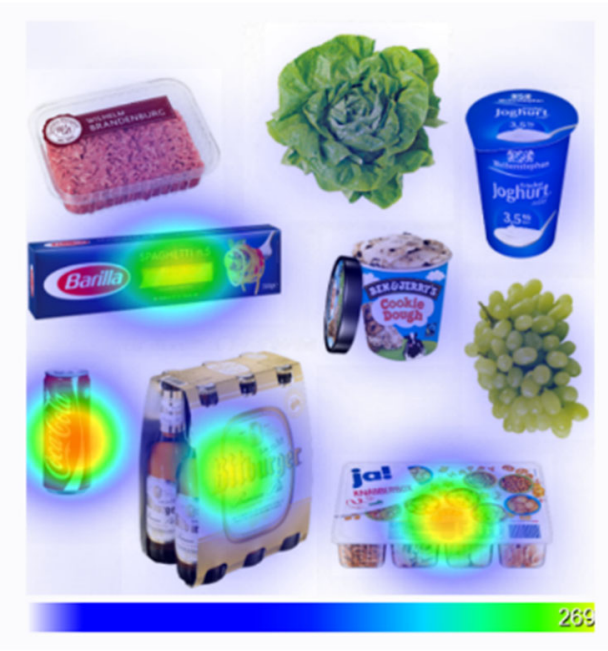

Fig. 1. Heat map of selected products (Source: compiled by author)

Results: Product Assortment

As can be clearly seen in the brightness of the heatmap, participants $(n=744)$ limited themselves to items that are logistically undemanding, meaning that they are not perishable and do not require refrigeration (dried pasta, soft drinks, beer, and crackers).

\section{Results: Online Shoppers/Non-Online Shoppers}

256 survey participants (31.1\%) answered "yes" to the question of whether they had already purchased groceries or drinks online at least once. This roughly corresponds to the findings of the bitkom study (Rohleder 2016) in which $28 \%$ responded affirmatively to this question.

The following question on shopper satisfaction yielded an astonishingly positive result - that $89 \%$ of online shoppers were satisfied with their purchase ( $42 \%$ were "very satisfied" and $47 \%$ were "rather satisfied"). This finding also correlates with the bitkom study in which the satisfaction rate was even somewhat higher, at $93 \%$ ( $47 \%$ very satisfied and $46 \%$ rather satisfied).

$11 \%$ of non-online shoppers indicated that they would "definitely" buy groceries online in the future. Strikingly, $37 \%$ of these non-online shoppers stated that they will "maybe" make such online purchases. Here too the findings are largely in accordance with the results of the representative bitkom study (Rohleder 2016), in which 6\% of non-online shoppers responded with "definitely" and 40\% with "maybe" when asked if they wanted to buy groceries online in the future.

\section{Results: Phase 1, Log-In/Check-in}

Both online shoppers and non-online shoppers expressed a clear preference for using the smartphone as their preferred device for online purchases, followed far behind by tablets, laptops, and PCs, with rates ranging from $14-20 \%$.

An interesting finding can be observed here regarding the extent to which collecting personal information during the sign-in process can serve as an impediment to buying groceries online. For shoppers, $35 \%$ indicated that this is a "very strong" impediment, and for non-online shoppers, that number was even higher, at $45 \%$.

\section{Results: Phase 2, Shopping/Product Assortment}

For certain types of product groups sold at brick and mortar stores, impulse purchases play a significant role. According to data provided by the Bundesverbandes der Deutschen Süßwarenindustrie e.V. (Association of the German Confectionary Industry), candy, for instance, belongs to the product groups most dependent on impulse buys (BDSI 2017). In over $70 \%$ of cases, consumers make a spontanous decision on what candy to put in the shopping cart first when they see the items on the shelves. For sellers in this product group, the survey presents a rather disappointing finding: when shopping online, only $22 \%$ of shoppers stated that they were "very willing" to make impulse buys in addition to the planned purchases on their grocery lists. For non-online shoppers, their reported willingness to make impulse buys online was even lower, at $19 \%$.

Given the option of seeing the price displayed in the shopping cart while shopping online, a clear preference emerges: both online shoppers (87\%) and non-online shoppers $(90 \%)$ prefer this option. 


\section{Results: Phase 3, Receiving/Delivery/Pick-Up}

The question about delivery time was directly related to the product assortment displayed at the beginning of the questionnaire. With $44 \%$, the highest proportion of responses fell within a window of 12-24 hours, both for online as well as non-online shoppers. Based on the average desired delivery time for online shoppers (19.2 hours) and nononline shoppers (17.5 hours), it can be concluded that the average expectation is for a delivery to take place with nextday service. Notable is also the proportion of participants who expect delivery to take place in fewer than 12 hours, i.e. same-day delivery, with $38 \%$ of online shoppers and $42 \%$ of non-online shoppers. The proportion of participants who accept longer delivery times is relatively low: only $19 \%$ of online shopppers and just $14 \%$ of non-online shoppers accept delivery times of longer than 24 hours.

Taking into consideration the numerous initiatives underway to provide emissions-free delivery of goods in "the last mile", such as the street scooter project from DHL (streetscooter), the survey asked participants about their opinion on having their goods delivered with a $100 \%$ electric transporter, making delivery both emissions-free and quiet. The results for both online shoppers and non-online shoppers are surprisingly similar. Not so surprising, however, is the fact that while the majority of respondents $(60 \%)$ find the environmentally friendly delivery option to be good, they are not inclined to pay more than the typical market price for it. This type of delivery was not of interest to $14 \%$, but more than a quarter $(26 \%)$ were willing to pay a small surcharge for environmentally friendly delivery service.

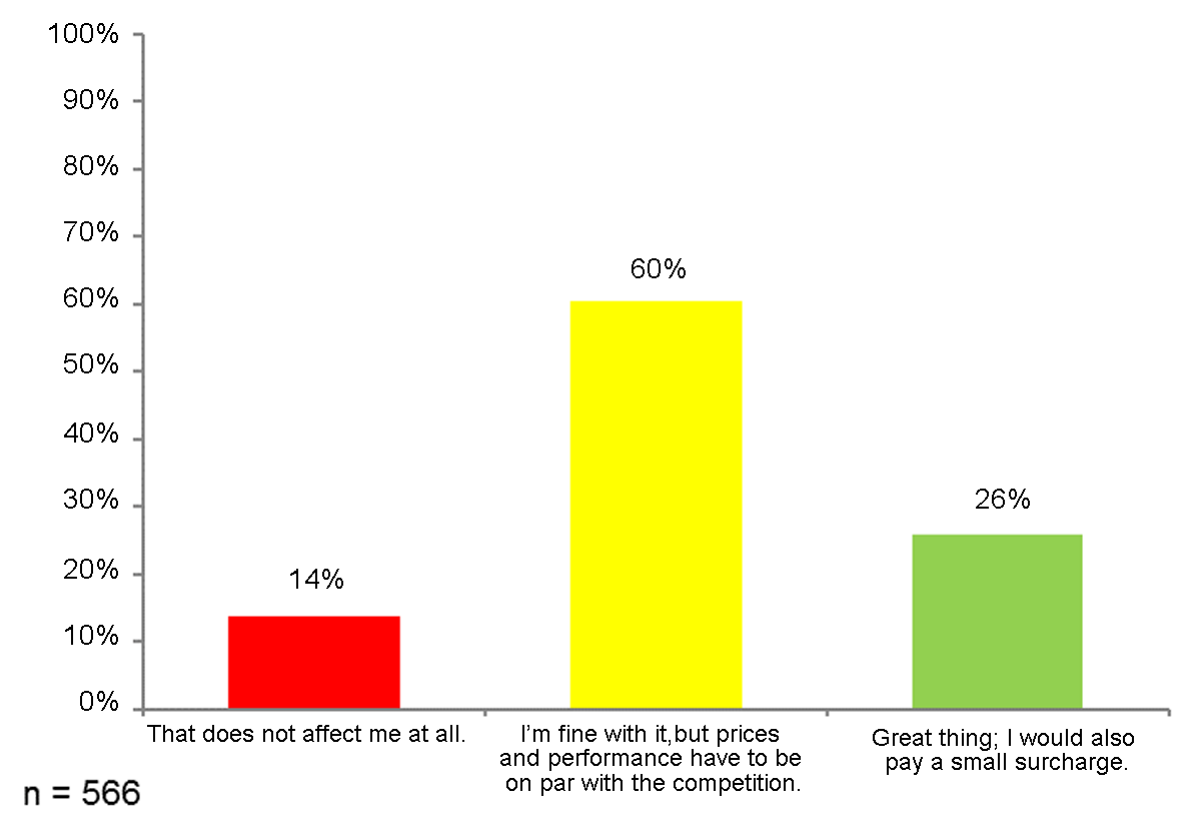

Fig. 2. Results for groceries being delivered with a $100 \%$ electric transporter (Source: compiled by author)

\section{Results: Phase 4, Payment/Check-out}

Online shoppers were given a question in which they were asked about the average order value of their online purchases. With $46 \%$, most of the responses fell into the category of "middle, between 20-50€." By including the averages from the other categories, an average order value of $44 €$ can be calculated.

\section{Results: Phase 5, Unpacking - Packaging/Disposal}

Groceries ordered online are delivered in a lot of protective packaging in order to ensure that they are not damaged during delivery. Survey participants were asked how problematic disposing of the considerable amount of packaging material is for them. The result here is unequivocal: both online shoppers $(64 \%)$ and non-online shoppers $(72 \%)$ alike consider this to be highly problematic.

\section{Discussion}

\section{Results: Product Assortment}

With regard to product assortment, the question arises as to whether an online retailer should only offer a limited selection or a full range of products. From a logistics standpoint, it is certainly more convenient to limit one's offerings to products that do not require refrigeration or a great deal of protective packaging for transport. Such limitations to the product assortment, however, would not be acceptable from a marketing or sales standpoint. Further developments will reveal whether online retailers will decide, for financial reasons, to remove products that are problematic to transport, such as frozen foods, from their online product range. 


\section{Results: Online Shoppers/Non-Online Shoppers}

Shoppers' astonishingly high satisfaction with their online grocery purchases can definitely be construed to pose a danger for brick and mortar stores. The challenge for established retailers should consist of supplementing their existing brick-and-mortar infrastructure with appealing online offerings and services (Kröger 2016). A good example of this is the "REWE Abholservice" (REWE pick-up service): shoppers order their groceries online, which can then be picked up directly at a brick-and-mortar REWE location (REWE).

\section{Results: Phase 1. Log-in/Check-in}

The clear preference for the smartphone as the preferred ordering device presents retailers with the task of optimizing their respective smartphone apps to provide a convenient shopping experience. Due the exceptional depth and breadth of the product assortment offered by full grocery stores, which carry up to 15,000 different items (EDEKA), this task does foreclose a particular challenge. Given the limited screen size of a smartphone, one can only speculate that other technologies could be used in the future to enable shoppers to view the product assortment, such as virtual reality glasses (Denstitt 2016). This idea of buying goods in virtual reality might lead to revolutionary changes in shopping groceries. Until now, each retailer presents a unique retail mix to all costumers (Zentes et al. 2017), which applies to both online and brick and mortar stores. With a "jump" in the virtual world, it would be possible to create individual retail mixes for customers. This can mainly be the case for store layout, product supply and shopping atmosphere (Burinskiene/Daskevic 2014). An accelerator of this development could be the integration of third party provider of virtual reality shopping environments as an interface between consumer and retail industry.

The results of this survey relating to collecting personal information during the sign-in process is a clear indication that the user's willingness to set up additional accounts that require their personal information to shop online is limited. This, in turn, could mean that existing platforms (e.g. Amazon) who offer a grocery shopping service alongside other services would have a competitive advantage, as the shopper would not need to set up an additional account with their login-in information.

\section{Results: Phase 2: Shopping/Product Assortment}

The results suggest that the majority of online shoppers only make "planned purchases" and show little willingness to let themselves be tempted by "impulse buys". Here the question arises as to how online grocery retailers can encourage shoppers to make such impulse purchases.

Given required minimum order values, displaying the total price of all goods in the online shopping cart is certainly a necessary functionality. Nevertheless, this information, which is generally not available to the customer shopping in a brick and mortar store, is surely also a considerable impediment to making impulse buys online.

\section{Results: Phase 3, Receiving/Delivery/Pick-Up}

Expectations regarding delivery times expressed by participants in this survey may present a challenge for players in this market. While it can be assumed that customer expectations for same-day and next-day delivery could be fulfilled in large cities and metropolitan areas, this requirement may actually prevent online shopping from spreading to more rural areas in the near future. More research is needed to determine whether shoppers from rural areas would actually be willing to accept longer delivery times.

The problem of shoppers being rather unwilling to pay a surcharge for more environmentally friendly delivery, such as using electric delivery vehicles for the last mile, will likely remain unresolved for the foreseeable future. A corrective for this could come from two different directions: first, through a change in attitude on the part of the consumer to actually pay for environmental value-added, and second, through technological progess in electric transportation, which would make electric-powered delivery vehicles as economically cost effective as gas-powered ones.

\section{Results: Phase 4, Payment/Check-out}

In the German grocery industry, profits as a percentage of revenue are on average around $1 \%$, while discounter grocery chain Aldi is able to raise this figure to about 2\% (Fassnacht, Königsfeld 2012). Taking this profitability as a benchmark, the profit from an average online order for groceries would be $0.88 €(2 \%$ of $44 €)$. Now, however, it must also be considered that additional costs arise for online retailers in comparison to brick and mortar stores, such as order picking, packing, handling before delivery, and the delivery itself, as well as processing of returns. It is hard to imagine that these costs can be kept under the expected profit of $0.88 €$ per order. As such, one can assume that on average, an online purchase and delivery generates a loss. Compensating for this using a delivery service fee would be one idea. However, great competitive pressure is already being felt here, especially by new players in the retail food market. Companies like All you need GmbH (a subsidiary of the Deutsche Post DHL) with their online platform Allyouneedfresh.de, for instance, waive the delivery fee for orders over $40 €$ (Allyouneedfresh).

In the battle for market share, retailers no doubt put up with losses to maintain their market presence (Binninger 2016). It can be inferred from this that the challenging task for retailers is to convince potential online customers to preferably order products with high profit margins. Nevertheless, a significant risk arises from this line of thinking, namely that customers actually order groceries online that have low profit margins. 


\section{Results: Phase 5, Unpacking - Packaging/Disposal}

Both online and non-online shopppers agree that disposing of large amounts of packaging material is a problem. This finding can lead one to conclude that delivering products that require a lot of packaging, such as frozen foods or delicate items like eggs, should be avoided. Strong resistance to this idea, however, can surely be expected from a marketing and sales standpoint. But perhaps this problem is a stimulus for completely new ideas for shipping groceries. Up to this point, all business models have offered and shipped goods using the same packaging and packing units that are used in brick and mortar stores. How would it be, for instance, if packaging that has been optimized for online delivery were used to ship items? This includes, for one, the special configuration of packaging to protect against damage that could occur during transport with courier, express, and parcel services, and second, packaging sizes that could be adapted for repackaging as shipment parcels to minimize wasted space. The pressure to minimize wasted space will increase with the ongoing demand for online groceries.

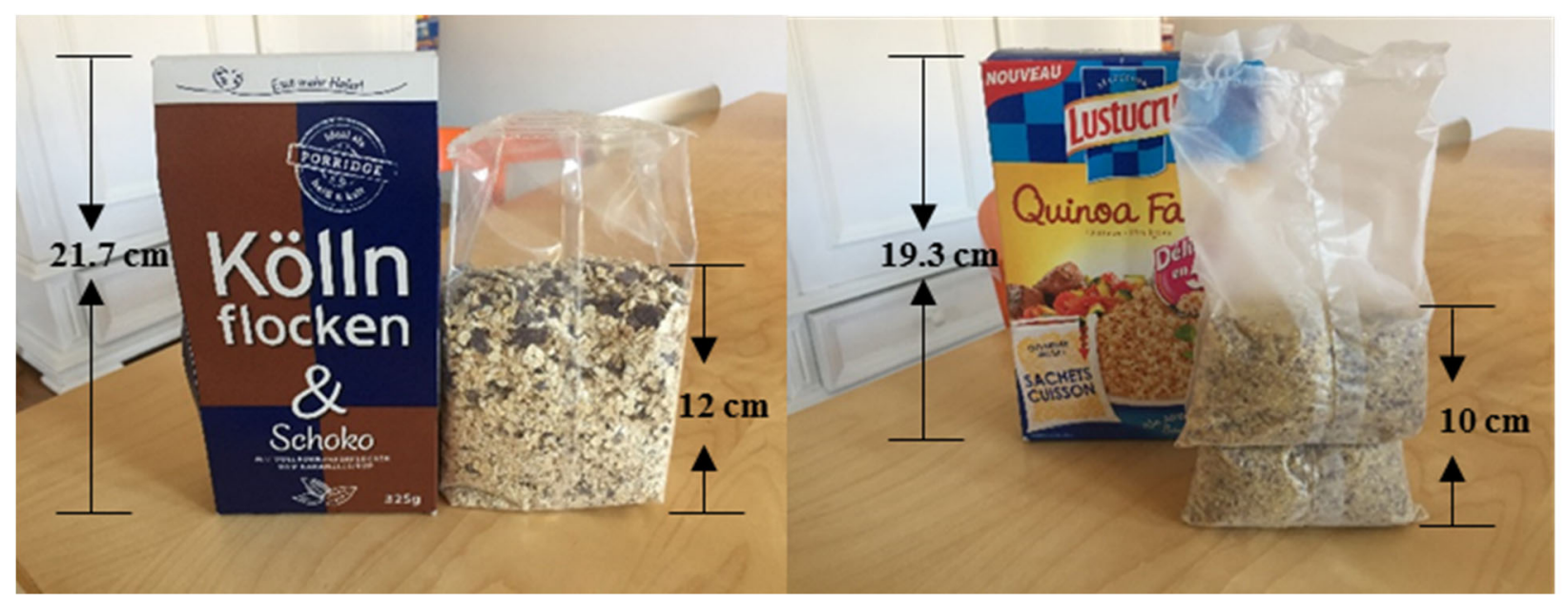

Fig. 3. Comparison of sales packaging and product packaging (Source: compiled by author)

To highlight the potential of wasted space, in Figure 3 two "logistic friendly" products were chosen. On the left side, the sales packaging of the breakfast cereal has the size (height $\times$ width $\times$ depth) of $21.7 \times 11.2 \times 5 \mathrm{~cm}$; which equates to $1,215.2$ cubic centimetre. The product packaging itself has meanwhile the dimension of $12 \times 11.2 \times 5 \mathrm{~cm}$ which equates to 672 cubic centimetre; which is only $55.3 \%$ of the sales packaging.

On the right side, the sales packaging of the Quinoa preparation has the size (height $\times$ width $\times$ depth) of $19.3 \times 12.2 \times 5.5 \mathrm{~cm}$; which equates to $1,295.03$ cubic centimetre. The product packaging itself has meanwhile the dimension of $10 \times 12.2 \times 5.5 \mathrm{~cm}$ which equates to 671 cubic centimetre; which is only $51.8 \%$ of the sales packaging.

If we take a look at the last step of the online grocery supply chain, we notice that delivery on the last mile is being done with light lorries or pickup cars, due to city traffic requirements. If we assume one could generally reduce the wasted space by approximately $50 \%$, one could stuff double as much packages in a delivery truck and therefore cut in half the transportation costs per package delivered.

To the last point, it is important to note that large packaging quantities or containers can improve transportation costs per item. On the other hand, such ideas do present food and drink manufacturers with new challenges, as they would have to pack and store the same product in two different types of packaging, depending on whether it is intended for sale online or at a brick and mortar store.

\section{Study limitations}

In order to reduce complexity for the purposes of this study, we did not model the complete range of product offerings at a typical supermarket or discount grocery store, nor did we investigate every phase of the shopping process. Instead, we attempted to generate a concrete image of the topic "food/drink" as an anchor (Kahnemann 2012) at the beginning of the survey, which served as a framework for the participants in the following questions. The difficulties associated with collecting relevant data in this field of study become apparent: if asking unsupported questions about food/drink, it is to be expected that the survey participants would randomly think about all different kinds of things that can be ascribed to food or drink. This in turn limits the analysis of the responses, as it is not known which answers relate to which particular food/drink. On the other hand, the visual anchoring method does exclude, more or less, random foods/drinks, which also accordingly limits the meaningfulness of the survey to only the selected foods and drinks. 
Derived from limitions of this study one can propose further research directions, such as:

- What are key influencing factors of consumers shopping groceries online?

- What is the ideal range of products being offered in platforms for online grocery?

- What typical demographic profile online shoppers have?

- Will there be soon tipping points in demand for online grocery that lead to closures of brick and mortar stores?

\section{Conclusions}

The market for groceries in Germany is estimated to be approximately 170 billion Euro per year (Kröger 2016). Even if, as according to estimates, only about $1 \%$ of this total turnover comes from online purchases, it is still noteworthy that one in three survey participants indicated that they had already bought food/drinks online. Even more striking, though, is the high degree of satisfaction indicated by shoppers in surveys. It is also striking because this sentiment was repeatedly not confirmed in a series of test purchases made by students at the University of Applied Sciences Ludwigshafen am Rhein. The main reason for this was delayed deliveries, orders split into different deliveries on different days, as well as discrepancies between ordered and delivered goods. In one case, for instance, a package of frozen strawberries was delivered instead of the fresh strawberries that had been ordered. According to the retailer's general terms and conditions, this was permitted, but the substitution ruined the shopper's plan to make a fresh strawberry cake.

One of the biggest challenges is to create a sustainable business model out of online grocery sales. Assuming that this branch has not yet proven to be profitable, there is actually cause for concern for operators of these platforms, especially if non-online shoppers, who said they will "definitely" or "maybe" make online grocery purchases, soon say "it's a deal," and buy online.

Finally, it is essential to monitor whether the trend of online shipping becomes something permanent. If this is the case, this should have an impact on the entire supply chain of the grocery food industry. And (perish the thought, for established retailers): what if manufacturers decided to start selling their products directly online themselves?

\section{Acknowledgements}

I would like to thank the undergraduate students majoring in logistics who participated in the Quality Management course during winter semester 2016/2017 at the University of Applied Sciences Ludwigshafen am Rhein for their many interesting ideas and stimulating discussions and Mrs. Carly Ottenbreit for editing this paper.

\section{Disclosure statement}

The author hereby declares that he has no relevant or material financial interests that relate to the research described in this paper.

\section{References}

Allyouneedfresh. 2017 [online], [cited 10 February 2017]. Available from Internet: https://www.allyouneedfresh.de/

Amazon eröffnet. 2016. Amazon eröffnet Lebensmittelladen ohne Kasse [online], [cited 23 February 2017]. Available from Internet: http://www.spiegel.de/wirtschaft/unternehmen/amazon-go-versandhaendler-testet-lebensmittelgeschaeft-ohne-kassen-a1124581.html

BDSI. 2017. Präsentation im Markt [online], [cited 31 January 2017]. Available from Internet: http://www.bdsi.de/warenkunde/bonbons-und-zuckerwaren/praesentation-im-markt/

Berens, S. 2016. Kraut und Rüben im Online-Lebensmittelhandel [online], [cited 17 February 2017]. Available from Internet: https://www.ehi.org/de/pressemitteilungen/kraut-und-rueben-im-online-lebensmittelhandel/

Binninger, F. M. 2016. Kaufmännisch wird Amazon keinen Spaß haben, Verkehrsrundschau 32-33, $20-23$.

Burinskiene, A.; Daskevic, D. 2014. Consumer demand: online or retail stores, Economics and Management 19(2): 172-186. https://doi.org/10.5755/j01.em.19.2.4742

Denstitt, K. 2016. Oculus Rift app will let you to visit a virtual showroom before you buy [online], [cited 2 March 2017]. Available from Internet: https://www.psfk.com/2016/01/vr-shopping-app-oculus-rift-google-cardboard-retale.html

Der Tengelmann-Deal. 2016. Der Tengelmann-Deal [online], [cited 10 February 2017]. Available from Internet: http://www.lebensmittelzeitung.net/themen/Ausverkauf-bei-Tengelmann

Deutsche Post DHL. 2012. Einkaufen 4.0. Der Einfluss von E-Commerce auf Lebensqualität und Einkaufsverhalten. Bonn.

EDEKA. EDEKA Einzelhandel [online], [cited 23 February 2017]. Available from Internet: http://www.edekaverbund.de/Unternehmen/de/edeka_minden_hannover/unternehmen_minden_hannover/einzelhandel_minden_hannover/mar kttypen_miha.jsp 
Fassnacht, M.; Königsfeld, A. 2012. Kommentar: Aldis Flirt mit den Marken, in Markenartikel [online], [cited 23 February 2017]. Available from Internet: http://www.markenartikel-magazin.de/no_cache/handel/artikel/details/1001872-kommentar-aldisflirt-mit-den-marken/?print=98

Gassmann, M. 2015. Warum wir Lebensmittel bald doch im Internet kaufen [online], [cited 2 March 2017]. Available from Internet: https://www.welt.de/wirtschaft/article144340416/Warum-wir-Lebensmittel-bald-doch-im-Internet-kaufen.html

Heitmeyer, C. 2012. Retail is detail \& retail goes mobile. Fünf Thesen warum der traditionelle Handel vom "All-Around-Handel" abgelöst werden wird, Deutsche Post DHL. Einkaufen 4.0. Der Einfluss von E-Commerce auf Lebensqualität und Einkaufsverhalten. Bonn, 54-59.

Kahnemann, D. 2012. Schnelles Denken, langsames Denken. Siedler: München.

Kröger, M. 2016. Rewe Chef Caparros zittert vor Amazon [online], [cited 16 February 2017]. Available from Internet: http://www.spiegel.de/wirtschaft/unternehmen/lieferdienste-rewe-chef-caparros-zittert-vor-amazon-a-1127754.html

Lichtner, C. 2015. eCommerce: Anteil bei Lebensmitteln und Drogerieartikeln wird sich verdoppeln. Pressemitteilung der GfK [online], [cited 23 February 2017]. Available from Internet:

http://www.gfk.com/fileadmin/user_upload/dyna_content/DE/documents/Press_Releases/2015/20150723_PM_GfKStudie_eCommerce_dfin.pdf

Maurer, M.; Jandura, O. 2009. Masse statt Klasse? Einige kritische Anmerkungen zu Repräsentativität und Validität von OnlineBefragungen, 61-73 in Jackob, N.; Schoen, H.; Zerback, T. (Eds.). Sozialforschung im Internet - Methodologie und Praxis der Online-Befragung. Berlin, Heidelberg: Springer.

REWE. 2017. Online einkaufen beim REWE Abholservice [online], [cited 10 February 2017]. Available from Internet: https://www.rewe.de/service/abholservice/

Rohleder, B. 2016. Aus E-Commerce wird M-Commerce. 06 Oktober 2016. Berlin.

Streetscooter. 2017 [online], [cited 10 February 2017]. Available from Internet: http://www.streetscooter.eu/

Zdrzalek, L. 2016. Der Angstgegner [online], [cited 10 February 2017]. Available from Internet: http://www.zeit.de/wirtschaft/2016-06/amazon-fresh-lebensmittel-handel-aldi-rewe-edeka-lidl

Zentes, J.; Morschett, D.; Schramm-Klein, H. 2017. Strategic Retail Management. $3^{\text {th }}$ ed. Wiesbaden: Springer Gabler. https://doi.org/10.1007/978-3-658-10183-1 